University of Nebraska - Lincoln

DigitalCommons@University of Nebraska - Lincoln

4-1997

\title{
Rates, Timing, and Cyclicity of Holocene Eolian Activity in North- Central United States: Evidence from Varved Lake Sediments
}

Walter E. Dean

U.S. Geological Survey, MS 980, Federal Center, Denver, Colorado 80225

Follow this and additional works at: https://digitalcommons.unl.edu/usgsstaffpub

Part of the Earth Sciences Commons

Dean, Walter E., "Rates, Timing, and Cyclicity of Holocene Eolian Activity in North-Central United States: Evidence from Varved Lake Sediments" (1997). USGS Staff -- Published Research. 300.

https://digitalcommons.unl.edu/usgsstaffpub/300

This Article is brought to you for free and open access by the US Geological Survey at DigitalCommons@University of Nebraska - Lincoln. It has been accepted for inclusion in USGS Staff -- Published Research by an authorized administrator of DigitalCommons@University of Nebraska - Lincoln. 


\title{
Rates, timing, and cyclicity of Holocene eolian activity in north-central United States: Evidence from varved lake sediments
}

\author{
Walter E. Dean \\ U.S. Geological Survey, MS 980, Federal Center, Denver, Colorado 80225
}

\begin{abstract}
Most of the sediment components that accumulated in Elk Lake, northwestern Minnesota, during the Holocene are autochthonous or biogenic, delivered to the sediment-water interface on a seasonal schedule, preserved in distinct annual laminae (varves). The main allochthonous component is detrital clastic material, as measured by bulk-sediment concentrations of aluminum, sodium, potassium, titanium, and quartz, that enters the lake mostly as eolian dust. The eolian clastic influx to Elk Lake was considerably greater during the mid-Holocene (8-4 ka) than it has been for the past $4000 \mathrm{yr}$, when periods of increased eolian activity correspond to the time of the Little Ice Age and the dust bowl. Geochemical records of eolian activity exhibit distinct cyclicities with dominant periodicities of 400 and $84 \mathrm{yr}$.
\end{abstract}

\section{INTRODUCTION}

Elk Lake is in north-central Minnesota in Itasca State Park at the headwaters of the Mississippi River (Fig. 1C) in pine-hardwood forest $80 \mathrm{~km}$ east of the present prairie-forest border (Fig. 1B). The region occurs at a "climatic triple junction" between the cold, dry arctic airstream to the north, a warmer and wetter Gulf of Mexico-Atlantic airstream to the south, and dry Pacific air from the west (Fig. 1A), resulting in a sharp climatic gradient across Minnesota. Variations in position and strength of these airstreams occur on all time scales from seasonal to multiannual. During the dry mid-Holocene (ca. 8-4 ka), the prairie-forest border migrated at least $100 \mathrm{~km}$ east of its present position, at which time Elk Lake was surrounded by oak-sagebrush-grass savanna (Whitlock et al., 1993).

The entire Holocene sediment section in the deepest part of Elk Lake (29.6 m; Fig. 1D) consists of millimetre-scale annual laminations (varves; Anderson et al., 1993). The sediment components that make up the varve laminations today are more than $90 \%$ autochthonous or biogenic $\left(\mathrm{CaCO}_{3}\right.$, biogenic $\mathrm{SiO}_{2}$, organic matter, iron and manganese oxyhydroxides, and iron phosphate) and have only a minor siliciclastic allochthonous component (Dean, 1993). The annual

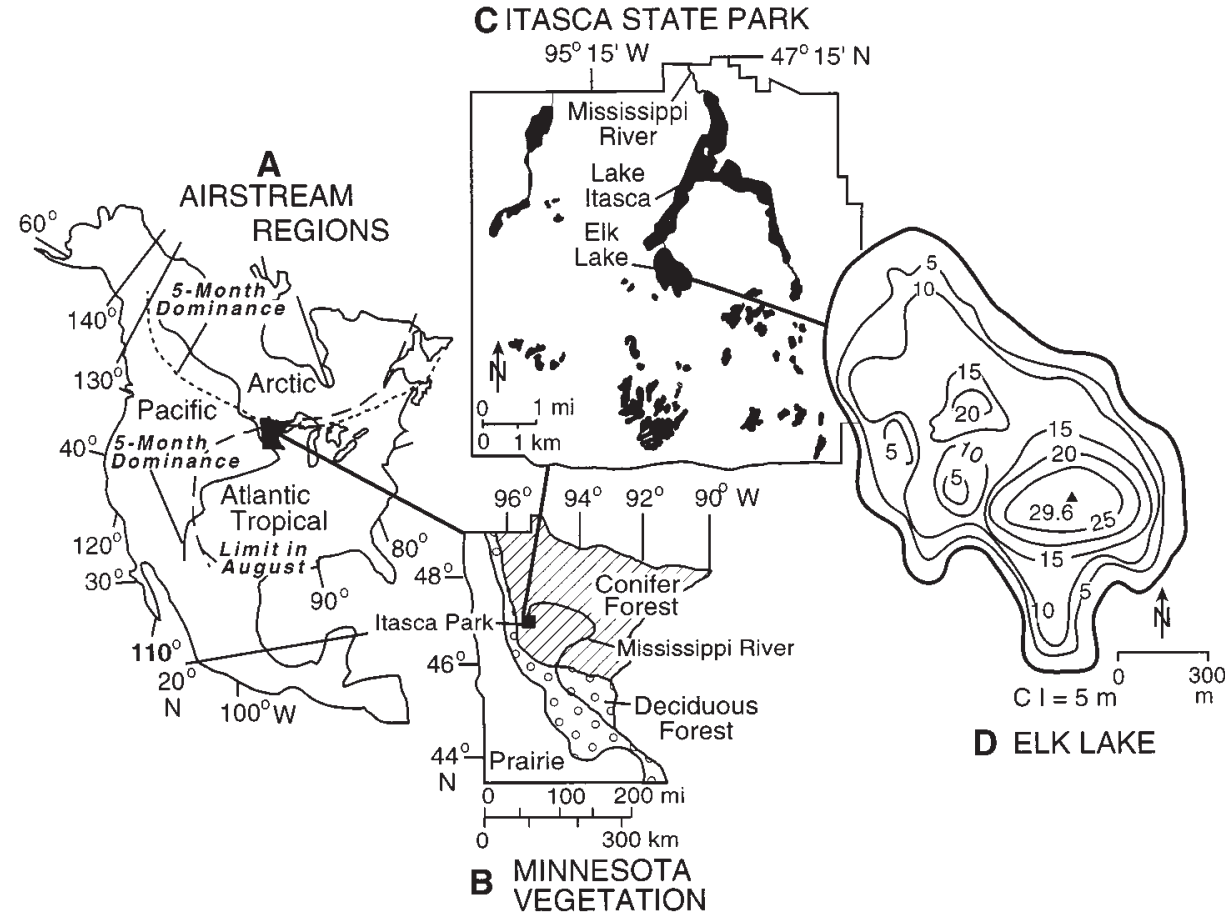

Figure 1. Maps showing (A) airstream regions in North America; (B) vegetation zones of Minnesota; (C) Itasca State Park with location of Elk Lake; (D) bathymetry of Elk Lake. chronometer provided by the varves permits highresolution calibration of climatic cycles with periods of a few years to several thousand years that are recorded in the chemistry and mineralogy of the sediments.

Results and interpretations of analyses of the entire Holocene section in Elk Lake based on a coarse sampling interval (50-yr composite samples) were presented in Bradbury and Dean $\left(1993^{1}\right)$. Geochemical analyses were performed on every other $50 \mathrm{yr}$ sample so that the geochemical results for the entire Holocene section presented by Dean (1993) and in this report have a $100 \mathrm{yr}$ resolution. Results of analyses of sediment sampled at a finer interval (5- or 10-yr composite samples) for the last $1500 \mathrm{yr}$ were presented by Dean et al. (1994¹). Major and traceelement analyses were performed on 10-yr composite samples; analyses of total and inorganic carbon, and X-ray diffraction mineralogy were performed on 5-yr composite samples. Subsequently, samples were collected at $1 \mathrm{~cm}$ intervals (representing an average of $2.5 \mathrm{yr}$ per sample) from a frozen box core for the interval from A.D. 1870 to 1984 . In this report, I describe changes in allochthonous and autochthonous sediment components as recorded in the chemical characteristics of the sediments over three telescoping time intervals: (1) the entire Holocene (past 10000 years); (2) the past $1500 \mathrm{yr}$; and (3) the past 114 yr (A.D. 1870-1984). I interpret these changes in terms of processes related to regional climate change as well as more local edaphic conditions, e.g., available moisture.

${ }^{1}$ Data from Bradbury and Dean (1993) and Dean et al. (1994) are available over the Internet as the "Elk Lake Data Set" from NOAA, National Geophysical Data Center Paleoclimate Program, Boulder, Colorado (ftp://ftp.ngdc.noaa.gov/paleo/elklake), or from W. E. Dean. 


\section{INDICATORS OF EOLIAN ACTIVITY}

Because no permanent streams enter Elk Lake, the small amount of detrital clastic material that is present in the sediments most likely was transported by wind. Concentrations and mass accumulation rates (in $\mathrm{mg} / \mathrm{cm}^{2} / \mathrm{yr}$ ) of many elements usually associated with detrital clastic material (e.g., aluminum, potassium, sodium, titanium, and several trace elements) all reached maximum values during the middle Holocene; much lower amounts of sediments were deposited during the past 3000 yr (Dean, 1993). These elements are represented in Figure 2 by aluminum (Al) and sodium $(\mathrm{Na})$. In addition, I use $\mathrm{Na}$ as a proxy for available moisture because the principal source of $\mathrm{Na}$ is plagioclase feldspar that is easily decomposed by hydrolysis with sufficient available moisture, releasing Na. During the dry mid-
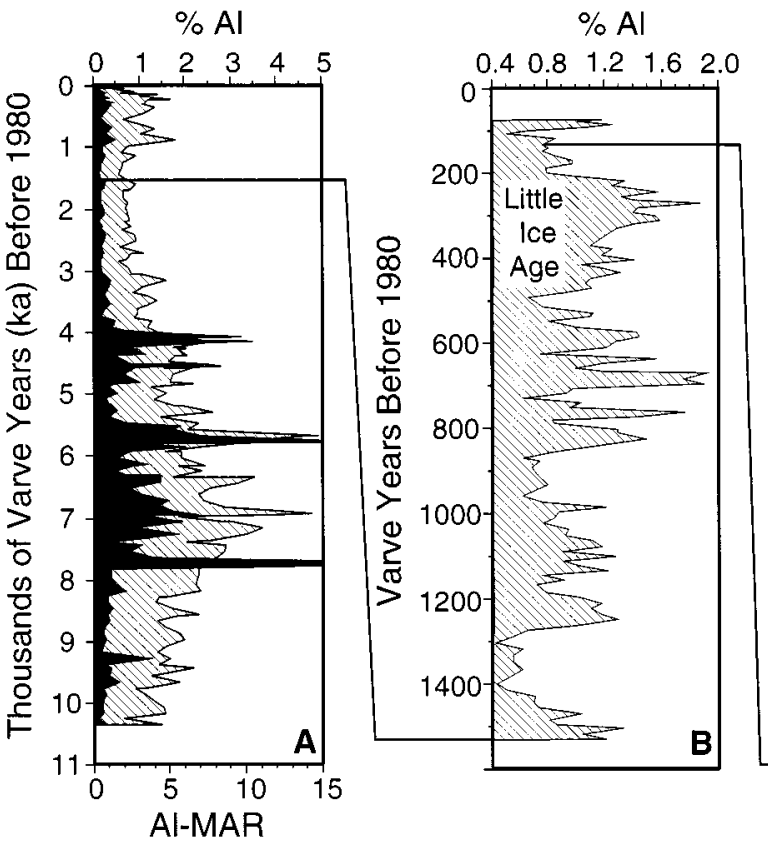

$\% \mathrm{Na}$

$\begin{array}{lllll}0 & 0.2 & 0.4 & 0.6 & 0.8\end{array}$

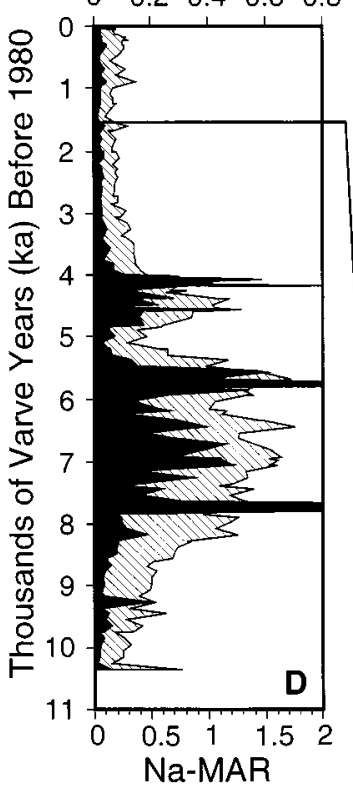

$\% \mathrm{Na}$

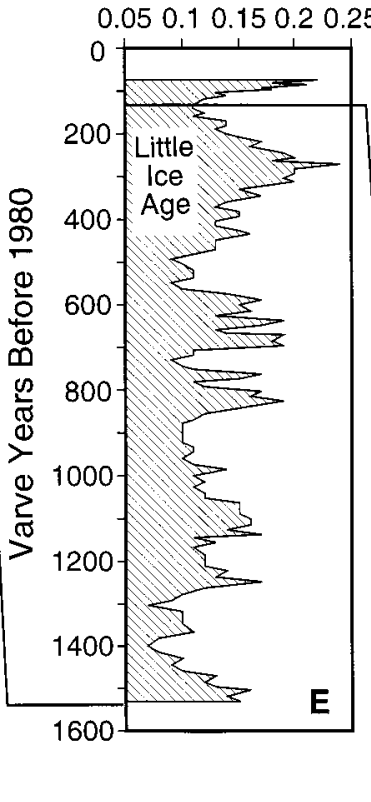

$\% \mathrm{Al}$

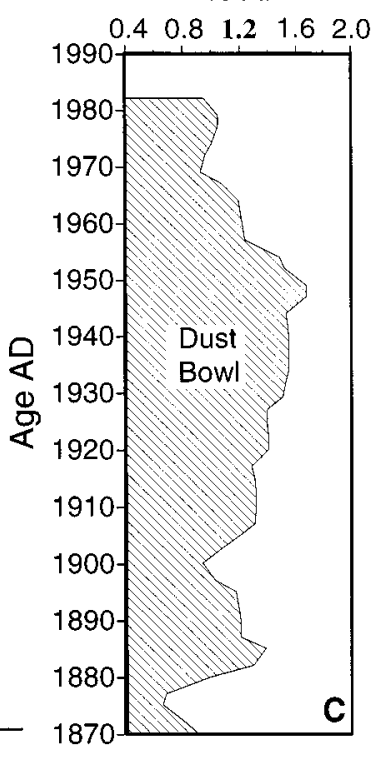

$\% \mathrm{Na}$

0.050 .10 .150 .20 .25

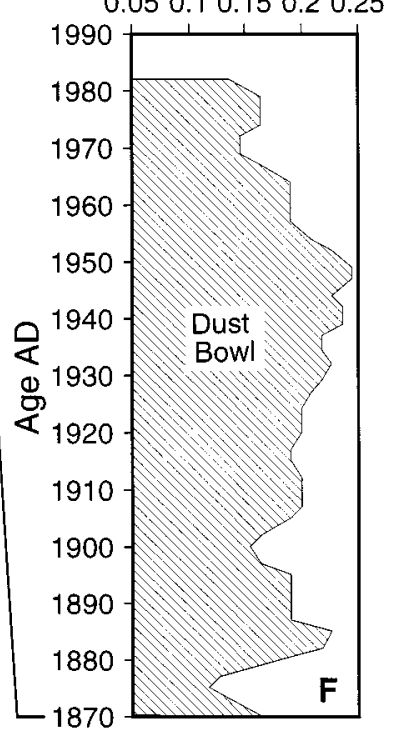

Figure 2. Profiles of (A) concentration (pattern) and mass accumulation rate (MAR in $\mathrm{mg} / \mathrm{cm}^{2} / \mathrm{yr}$; black) of aluminum (Al) in sediments of Elk Lake for the past $10000 \mathrm{yr}$; (B) \%Al for the past $1500 \mathrm{yr}$; (C) \%Al for the past $114 \mathrm{yr}$; (D) concentration (pattern) and MAR (in mg/cm $2 / \mathrm{yr}$; black) of sodium (Na) for the past $10000 \mathrm{yr} ;(E) \% \mathrm{Na}$ for the past $1500 \mathrm{yr}$; and $(\mathrm{F}) \% \mathrm{Na}$ for the past $114 \mathrm{yr}$. All values are on carbonate-free weight percent basis. Note difference in scales for \%Al between $A$ and $B+C$, and for \% Na between $D$ and $E+F$.

Holocene prairie period in Minnesota when available moisture was lower, less plagioclase was decomposed and the concentration of Na relative to the total detrital fraction increased. This lower decomposition of plagioclase is confirmed by mineralogical studies (Dean, 1993) that show that plagioclase was most abundant in mid-Holocene sediments in Elk Lake. Other proxy variables that indicate greater influx of eolian dust to the site of Elk Lake during the mid-Holocene are increased concentrations of silt-size quartz and increased magnetic susceptibility (Sprowl and Banerjee, 1989; Bradbury et al., 1993; Dean et al., 1996). The increase in influx of eolian clastic material during the mid-Holocene also produced varves that are much thicker than those formed over the past 4 k.y. from predominantly autochthonous components (Anderson, 1993). This evidence for increased mid-Holocene eolian activity from the sediments of Elk Lake is set in a background of evidence for active dune migration in Minnesota and the Great Plains (Dean et al., 1996).

Figure 2, A and D, shows that the concentrations and mass accumulation rates of $\mathrm{Al}$ and $\mathrm{Na}$ in sediments that accumulated in Elk Lake over the past $3 \mathrm{k} . \mathrm{y}$. are considerably less than those in sediments that accumulated between 8 and $4 \mathrm{ka}$. Specifically, the average $\mathrm{Al}$ accumulation rate in sediments deposited in the mid-Holocene between 7.8 and $5.5 \mathrm{ka}$ is seven times higher than the average $\mathrm{Al}$ accumulation rate in sediments deposited over the past 3 k.y. By comparing Na accumulation rates between the same two periods, the average mid-Holocene $\mathrm{Na}$ accumulation rate is 17 times higher, reflecting the lower decomposition of plagioclase during the mid-Holocene.

Even at the coarse sampling interval of the data plotted in Figure 2, A and D, there are peaks in concentrations and mass accumulation rates of $\mathrm{Al}$ and $\mathrm{Na}$ in sediments deposited during the past $1000 \mathrm{yr}$. When we examine the last $1500 \mathrm{yr}$ of the Elk Lake record (Fig. 2, B and E), cyclic variations at several different scales are apparent, but the most obvious are three groups of peaks about $400 \mathrm{yr}$ apart centered at 1200-1000 yr, $800-600 \mathrm{yr}$, and 400-200 yr ago. Half of a fourth 400-yr peak can be seen at $1500 \mathrm{yr}$ ago. The youngest and largest group of peaks corresponds in time (400-200 yr ago) to the main phase of the Little Ice Age (A.D. 1550-1700; Lamb, 1977), and the highest concentrations correspond in time to the Maunder sunspot minimum (A.D. 1640-1710). The interpretation of greater eolian activity to explain most of the increased influx of detrital clastic material to Elk Lake during the midHolocene is supported by evidence of increased eolian activity at the same time from numerous localities (Dean et al., 1996). If this interpretation is correct and can be extended to the late Holocene, then the Elk Lake record suggests that northwestern Minnesota was windier and dustier at several times during the past $1500 \mathrm{yr}$, relative to 3000 to 
$1500 \mathrm{yr}$ ago, and that this eolian activity reached a maximum during the Little Ice Age. The Little Ice Age actually is the culmination of a series of late Holocene glacial advances (neoglaciation; Porter and Denton, 1967). Several lines of evidence suggest that the beginning of the mid-Holocene "prairie period" in Minnesota was cold and dry, at least until about $6.8 \mathrm{ka}$ (Bradbury et al., 1993), not warm and dry as is usually interpreted for the midHolocene "altithermal." The point is that aridity, not temperature, is the main variable controlling eolian activity. The most recent periods of eolian activity recorded in Elk Lake may or may not be related directly to neoglaciation, but they almost certainly are related to regional aridity in North America that caused active dune migration over large areas of the Great Plains several times during the past several thousand years (see review by Dean et al., 1996) and also caused increased salinity of lakes in the Northern Great Plains (Fritz et al., 1994).

An examination of the Elk Lake record since A.D. 1870 (Fig. 2, C and F) shows peaks in concentrations of both $\mathrm{Al}$ and $\mathrm{Na}$ during the first half of the twentieth century. It is tempting to relate these increases to logging in Itasca Park between 1903 and 1919, but the greatest concentrations occur in sediment deposited between about 1930 and 1950, suggesting that greater clastic influx is related to increased regional aridity associated with the dust bowl decades. This dust bowl peak in eolian activity is confirmed in Figure 3B by another eolian proxy, quartz concentration as measured by relative X-ray diffraction peak height. This period is also marked in the Elk Lake cores by an increase in concentration of plagioclase feldspar (Dean et al., 1994) suggesting a decrease in available moisture. Both $\mathrm{Al}$ concentration (Fig. 3A) and, especially, quartz peak height (Fig. 3B) suggest that eolian activity was greater during the dust bowl years than during the Little Ice Age, and both periods of activity were not as great as mid-Holocene eolian activity (Fig. 2, A and D).

There appears to be cyclicity at several periodicities in the data for $\mathrm{Al}$ and $\mathrm{Na}$ in the Elk Lake record for the past $1500 \mathrm{yr}$ (Fig. 2, B and E). To objectively test for periodic components, I applied singular spectrum analyses (Dettinger et al., 1995) to the data for Al (Figs. 2B and 4A). Singular spectrum analysis breaks down time series into reconstructed periodic components. The analysis showed that the reconstructed spectral component that explained the largest single fraction of the variance $(28.3 \%)$ was the long-term (1600 yr) trend in the data. The second most significant reconstructed component is a $400 \mathrm{yr}$ cycle that explained $21.5 \%$ of the variance (Fig. 4B). This is the cycle that can be seen in the three groups of peaks in the Al data. The singular spectrum analysis also identified an 84 yr reconstructed component (Fig. 4C), which accounts for $14.1 \%$ of the variance, that is best developed in the middle of

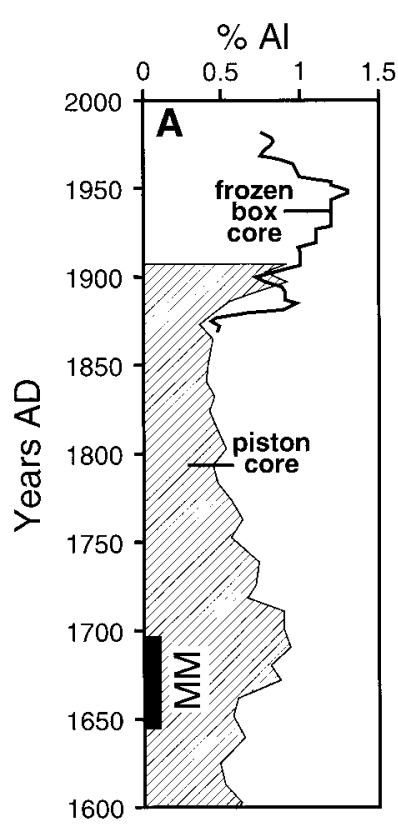

Peak Height 0200400600800

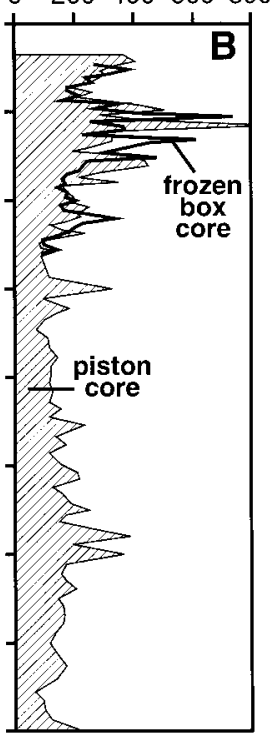

Figure 3. Profiles of (A) \%Al and (B) X-ray diffraction peak height for quartz in varved sediments deposited in Elk Lake since A.D. 1600. MM indicates time interval of Maunder sunspot minimum.
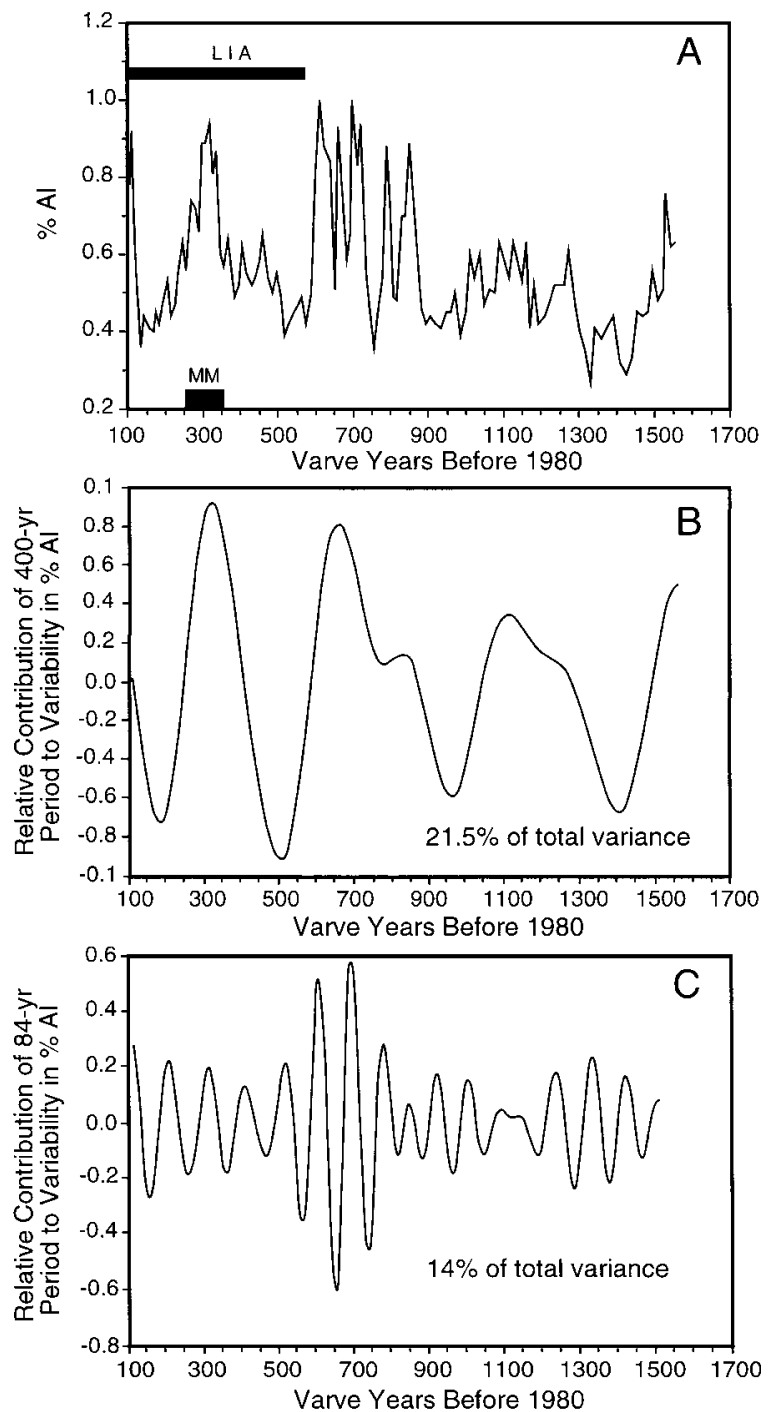

Figure 4. (A) Plot of \%Al in bulk sediment in Elk Lake versus time in varve years. This plot differs from Figure 2B, which shows $\% A l$ on carbonate-free basis. MM indicates time interval of Maunder sunspot minimum, and LIA indicates time interval of Little Ice Age. B: Relative contribution of $400 \mathrm{yr}$ period reconstructed by singular spectrum analysis for $\%$ Al data in sediments of Elk Lake. C: Relative contribution of $84 \mathrm{yr}$ period reconstructed by singular spectrum analysis for \%Al data in sediments of Elk Lake. 
three 400 yr cycles (ca. 600-900 varve years). Additional significant periodic components were identified with periods of about 190, 60, and 40 yr. Anderson (1993) found a prominent $200 \mathrm{yr}$ periodicity in varve thickness in Elk Lake sediments deposited between 7300 and 5300 yr ago that he related to the $200 \mathrm{yr}$ Suess cycle in ${ }^{14} \mathrm{C}$ production. This $200 \mathrm{yr}$ cycle does not seem to be present in the Elk Lake Al record, but the second most prominent periodicity in Anderson's varve thickness data was 40 to $50 \mathrm{yr}$, and that may correspond to the 60 and 40 year periods in the $\mathrm{Al}$ data. This, together with the coincidence of peak eolian activity with the time of the Maunder sunspot minimum, suggests that there may be a solar connection to the most recent periods of eolian activity recorded in Elk Lake, but this connection is highly speculative.

\section{CONCLUSIONS}

The mid-Holocene (ca. 8-4 ka) varved-sediment record in Elk Lake, Minnesota, documents pulses of increased influx of eolian dust and decreased available moisture. The geochemical record in Elk Lake for the past $1500 \mathrm{yr}$ indicates that there were cyclic fluctuations in both eolian activity and available moisture in northwestern Minnesota with a dominant periodicity of $400 \mathrm{yr}$. These dry, windy conditions were most pronounced 200-400 yr ago, coincident with the Little Ice Age, and during the dust bowl decades of the 20th century. However, these more recent dry, windy periods were not nearly so severe as those of the mid-Holocene, which was also the period of most active dune formation throughout the Great Plains.

\section{ACKNOWLEDGMENTS}

The research was supported by the U.S. Geological Survey Global Change and Climate History Program. I thank Platt Bradbury, Rick Forester, Eric Leonard, Rich Madole, Dave Rea, and Michele Tuttle for helpful reviews.

\section{REFERENCES CITED}

Anderson, R. Y., 1993, The varve chronometer in Elk Lake: Record of climatic variability and evidence for solar/geomagnetic- ${ }^{14} \mathrm{C}$-climate connection, in Bradbury, J. P., and Dean, W. E., eds., Elk Lake, Minnesota: Evidence for rapid climate change in the north-central United States: Geological Society of America Special Paper 276, p. 1-6.

Anderson, R. Y., Bradbury, J. P., Dean, W. E., and Stuiver, M., 1993, Chronology of Elk Lake sediments: Coring, sampling, and tine-series construction, in Bradbury, J. P., and Dean, W. E., eds., Elk Lake, Minnesota: Evidence for rapid climate change in the north-central United States: Geological Society of America Special Paper 276, p. 37-44.

Bradbury, J. P., and Dean, W. E., eds., 1993, Elk Lake, Minnesota: Evidence for rapid climate change in the north-central United States: Geological Society of America Special Paper 276, 336 p.

Bradbury, J. P., Dean, W. E., and Anderson, R. Y., 1993, Holocene climatic and limnologic history of the north-central United States as recorded in the varved sediments of Elk Lake, Minnesota: A synthesis, in Bradbury, J. P., and Dean, W. E., eds., Elk Lake, Minnesota: Evidence for rapid climate change in the north-central United States: Geological Society of America Special Paper 276, p. 309-328.

Dean, W. E., 1993, Physical properties, mineralogy, and geochemistry of Holocene varved sediments from Elk Lake, Minnesota, in Bradbury, J. P., and Dean, W. E., eds., Elk Lake, Minnesota: Evidence for rapid climate change in the north-central United States: Boulder, Colorado, Geological Society of America Special Paper 276, p. 135-157.
Dean, W. E., Bradbury, J. P., Anderson, R. Y., Bader, L. R., and Dieterich-Rurup, K., 1994, A highresolution record of climatic change in Elk Lake, Minnesota for the last 1500 years: U.S. Geological Survey Open-File Report 94-578, 127 p.

Dean, W. E., Ahlbrandt, T. S, Bradbury, J. P., and Anderson, R. Y., 1996, Regional aridity in North America during the middle Holocene: The Holocene, v. 6, p. 145-155.

Dettinger, M. D., Ghil, M., Stong, C. M., Wibel, W., and Yiou, P., 1995, Software expedites singular-spectrum analysis of noisy time series: Eos (Transactions of the American Geophysical Union), v. 76, no. 2 , p. $12,14,21$.

Fritz, S. C., Engstrom, D. R., and Haskell, B. J., 1994 Little Ice Age aridity in the North American Great Plains: A high-resolution reconstruction of salinity fluctuations from Devils Lake, North Dakota, USA: The Holocene, v. 4, p. 69-73.

Lamb, H. H., 1977, Climate-Past, present, and future, Volume 2, Climatic history and the future: London, Methuen, $835 \mathrm{p}$.

Porter, S. C., and Denton, G. H., 1967, Chronology of neoglaciation in the North American cordillera: American Journal of Science, v. 265, p. 117-210.

Sprowl, D. R., and Banerjee, S. K., 1989, The Holocene paleosecular variation record from Elk Lake, Minnesota: Journal of Geophysical Research, v. 94, p. 9369-9388.

Whitlock, C., Bartlein, P. J., and Watts, W. A., 1993, Vegetation history of Elk Lake, in Bradbury, J. P., and Dean, W. E., eds., Elk Lake, Minnesota: Evidence for rapid climate change in the north-central United States: Geological Society of America Special Paper 276, p. 251-276.

Manuscript received September 30, 1996 Revised manuscript received December 11, 1996 Manuscript accepted December 13, 1996 